Article

\title{
It's in the Water: Byzantine Borderlands and the Village War
}

\author{
Jason Moralee \\ Department of History, University of Massachusetts Amherst, Amherst, MA 01003, USA; \\ jmoralee@history.umass.edu
}

Received: 6 August 2018; Accepted: 14 August 2018; Published: 27 August 2018

\begin{abstract}
This essay examines Byzantine military manuals created between the sixth to the tenth centuries for what they can reveal about Byzantine imperial attitudes toward the landscapes of war and those who inhabit them. Of foremost concern in these sources is the maintenance of 'security' (Greek: asphaleia) by commanders with the necessary quality of 'experience' (Greek: peira). Experience meant knowing how to best exploit the land, including the villages under Byzantine authority, in the prosecution of war. Exploitation in the name of security involved destroying villages, using villages and their inhabitants in ambushes, poisoning and seizing crops, evacuating villages, and using villages for the billeting of, at times undisciplined, soldiers. Villages were thus central to a Byzantine military strategy that is identified here as the 'village war,' a strategy that is analogous to security strategies evident in more recent conflicts. Through the juxtaposition of premodern and modern modalities of war, this essay intends to be a pointed reminder that the village war has deep roots in imperialist thought, and that the consequences of the village war profoundly reshape the lives of those caught up in its midst, particularly the peasantry.
\end{abstract}

Keywords: borderland; Byzantine empire; experience; Goths; imperialism; Islamic State; peasant; Pseudo-Joshua the Stylite; rural; security; Theophanes the Confessor; village; warfare

\section{1. 'We Can Never Go Back to Our Village, or We Will Die'}

By the beginning of August, 2014, Islamic State (IS) had taken the city of Sinjar and pillaged the surrounding villages in northwestern Iraq. The scale of this disaster shocked the world. As they stormed into Yazidi villages, IS fighters took thousands of women and children captive. Tens of thousands of Yazidi refugees fled their homes, squeezing themselves and whatever they could carry onto pickup trucks and tractors. These caravans of people fleeing crowded the roads across Kurdistan. Thousands sought refuge on the Yazidi holy mountain, Mount Sinjar. The mountain was barren; especially troubling was the fact that the only available water came from shallow streams. To quench the thirst of their children, it was reported that parents resorted to spitting in their mouths. Increasing numbers escaped into territory controlled by Kurdish militias only to find themselves living in makeshift camps. One thing was clear. Even as children begged to go home, they were met by the resignation of their parents. As one father said, 'We can never go back to our village, or we will die.' Meanwhile, fearing the collapse of nearby Erbil and the Kurdish bulwark against IS, President Obama authorized the delivery of relief by military aircraft: bombs for the militants and food for the refugees. More devastation followed. By summer 2015, one million people, many from this region, boarded 
rickety boats and crossed into Europe, and since then thousands of men, women, and children have died in the attempt. ${ }^{1}$

Sinjar was an international story. The world watched in horror as journalists captured images of people gathered on this desolate mountain top and filed reports about the banality of massacre and slavery for IS militants as they moved their battle forces across the frontier zone between Turkey, Syria, and Iraq. We want to believe that there is something essentially premodern and nonwestern about IS and its tactics. They are the new barbarians standing at the gates of the capitalist world system. But thinking thus is to engage in a sort of 'mnemonic myopia.' ${ }^{2}$ In fact, this is an old story told through new media. Reflection on the past turns the specificity of the present horror into the sad recognition that these habits of degradation have haunted humanity for thousands of years. Interstate warfare is played out in borderlands, its theatre of combat focused on villages, its victims peasants, its signature streams of refugees. These displacements of war are, to borrow a phrase from a journalist covering more recent conflicts, part of the nervous system of people in war zones. ${ }^{3}$ Moreover, the catalyst contributions for this Special Issue invite us to see that the displacements of war become an inheritance passed on from one generation to the next, a 'refugee heritage' that redefines what it means to say that you are home-a condition of being from places that you can not return to, and of living in places that are not your own. ${ }^{4}$

At the same time that IS fighters are being denounced as unthinkable barbarians, there has been a growing nostalgia for western imperialism. A chorus of apologists for the European empires of the past and the brutal machinery of colonial exploitation is becoming increasingly heard in public discourse. ${ }^{5}$ The purpose of this essay is a reminder of the simple fact that imperialist and authoritarian regimes have always established their authority by controlling the countryside and its inhabitants. To illustrate this point, this essay looks for the displacements of war in the Byzantine borderlands, focusing roughly on the same region afflicted by IS and the ambitions of a long list of combatants that stretches from the present into the distant past: western Asia along the borderlands of the modern states of Turkey, Syria, and Iraq. I would like to chart the difference between the perceptions that Byzantine imperial actors had of the borderlands and their inhabitants, and the consequences of these perceptions for the peasantry. ${ }^{6}$ This investigation is particularly interested in how the deployment of ideologically charged words like 'strategy,' 'experience,' and 'security,' created the necessary conditions for the destruction of villages and the routine displacement of villagers from their homes.

The sources for this essay are a series of military manuals written by Byzantine army commanders first in the late sixth century and then again in the tenth century. ${ }^{7}$ They are part of a long Graeco-Roman tradition of writing about strategy. In this sense, the military manuals are in places derivative and as a whole prescriptive, setting forth what ought to be done rather than describing particular situations. They were written in simple Greek prose and made for the practical instruction of those going into the theatre of war. They are not field reports, nor do they record the voices of those most affected by war-the peasantry. It is also worth pointing out that the Byzantine polity changed dramatically between the sixth and tenth centuries, as did its adversaries. These changes included the size of

1 Quotation: Rubin (2014); US bombing campaign: Landler et al. (2014); Captives: Shefler (2014). Number of deaths: Missing Migrants Project (2013-2018).

2 Zerubavel (2003, p. 92).

Prashad (2017b).

See especially the contributions by Petti (2017); Dalal (2017); Maqusi (2017).

Emblematic is the heated exchange between Niall Ferguson and Pankaj Mishra in the London Review of Books, 3 November 2011: https:/ / www.lrb.co.uk/v33/n21/pankaj-mishra/watch-this-man. More recently, the journal Third World Quarterly published and later retracted a highly flawed essay titled 'The Case for Colonialism.' See Prashad (2017a); Andrews (2016) and Tripathi (2018) report on the growth of colonial and imperial nostalgia in the UK. Colonial and imperial nostalgia is also percolating elsewhere, for example, in Turkey, the United States, and Russia.

6 The real and imagined frontiers between Byzantium and dâr al-Islâm has been discussed in Eger (2015, pp. 1-21). Further views of Byzantium, borderlands, and warfare in this period: El-Cheikh (2004, pp. 83-93).

7 See (Dain 1967; Dennis 1981, pp. 13-42; Dennis 1984, pp. vii-xxiii; Dennis 1985, pp. 1-7, 137-41, 241-44). 
Byzantine territory, supplying the army, the recruitment of soldiers, the organization of provinces, and the challenges to the emperor's claims on territory, especially the establishment of Islamic polities in the seventh century along the Mediterranean littoral and the more or less permanent state of warfare that ensued. ${ }^{8}$ Despite the limitations of the sources and the many significant changes that affected Byzantine governance in these centuries, the military manuals are nevertheless consistent in showing that one of the primary concerns of combatants on either side of the Byzantine frontier were the villages of the homeland. ${ }^{9}$

\section{Defending Romanía: Experience, Security, and Landscape}

For Byzantine military commanders, the battlefield was a theatre in which reason and experience led to a successful performance of one's role as defender of the homeland. This homeland is described in different terms, but it is often portrayed as a territory with knowable boundaries, and subject to the sacred authority of the emperor in Constantinople. ${ }^{10}$ The opening lines of the late sixth-century Stratêgikon, which is attributed to the emperor Maurikios, state that the work was undertaken through 'devotion to the politeia' (pros tên politeian hormêthentes). ${ }^{11}$ In the tenth-century Peri Paradromês (On Skirmishing), the homeland is called Romanía; 'our regions' (chôrai) are specified as opposed to their chôra, and these regions have discernable 'boundaries' (akra). ${ }^{12}$ Another manual points to 'those who dwell on the borders of the Roman realm (akra tês Rhômaiôn archês) and have our enemies as neighbours.'13 Ringed about by neighbours like these, this latter-day Roman empire needed officers up to the task. The military manuals enumerate the best qualities that commanders should demonstrate. 'Inexperience' (apeira) leads to disaster while 'experience' (peira) is fundamental for acquiring better knowledge of tactics, success, and the landscapes of war. ${ }^{14}$ Like other late Roman officials, the commander should exemplify justice and judgment through his simple mode of life and the deliberate ways in which he makes difficult decisions. According to the anonymous tenth-century Peri Stratêgias (On Strategy), 'the general should be courageous in his resolve (andreion têi gnômêi), naturally suited for command, profound in his thinking, sound in his judgment, in good physical condition, hardworking, emotionally stable. ${ }^{15}$ These qualities would allow the commander to successfully lead the army on campaign. But success, we are repeatedly told, was ultimately in divine hands. The battlefield was thus also a place where the slaughter of the enemy and the plundering of their territory was evidence of both the commander's experience and the favour of the Christian god and the Virgin Mary. ${ }^{16}$

For what follows, it is important to see the campaigning army as an officially sanctioned mobile population consisting of multiple battle units, a baggage train, slaves, and at times the family members

8 Haldon (1999) expertly surveys these changes. It is not my intention here to lay out with precision how these many fundamental changes in the constitution and deployment of the Byzantine army affected the treatment of rural populations inside and outside the borderlands of the empire. For discussions of these changes, see (Grosse 1975; Haldon and Kennedy 1980; Kaegi 1981, 1982; Haldon 1995a, 1995b; McGeer 1995; Treadgold 1995; Krsmanović 2008; Eger 2015).

9 McGeer (1991).

10 Kaldellis (2017)

11 Stratêgikon Praef. (Dennis 1981; Dennis 1984).

12 Romanía, 'our chôrai,' and theirs: Peri Paradromês 4, 7, 20 (Dennis 1985). Boundaries (akra or akrai) of themes: Peri Paradromês 2. Borderlands: Peri Paradromês 3, 6, 7 .

13 [Anônymou Biblion taktikon] [28] (Dennis 1985).

14 Stratêgikon Praef.

15 For officials: Anon. Peri Stratêgias 3 (Dennis 1985); for generals: Anon. Peri Stratêgias 4 (adapted trans.).

16 Stratêgikon, Praef. Dennis (2001) strongly asserts that Byzantium waged war with extreme caution. In spite of references like this one, which discuss waging war in the name of the Virgin (e.g., Evagrius Scholasticus, HE 4.24), Dennis argues that Byzantines did not think of their wars as 'holy wars.' Of course this is a definitional problem subject to different interpretations. It is not my intention here to argue that the routinized forms of frontier maintenance reflected in the military manuals were thought of as somehow 'holy.' One can certainly observe that Byzantine religious ideology pervades the military manuals, energizing and justifying military action. 
of the soldiers, including children. ${ }^{17}$ Indeed, the military manuals sometimes call the soldiers oikeioi: while on the march the soldiers (oikeioi) were thus considered as dependents within the commander's household (oikos). ${ }^{18}$ As this military household and its pater-commander moved through a landscape dotted with villages (chôria), it was assumed that the soldiers would regularly need to find and procure food, water, and other supplies. This necessity was also included in the commander's performance of his knowledge and experience. According to the Stratêgikon, 'The general should know [katanoeitô] the country [chôrion] well, whether it is healthy or safe or unhealthy for his troops and inhospitable, and whether the necessities such as water, wood, and forage are nearby. ${ }^{19}$ Advice fills the manuals for how, and under which circumstances, to procure resources from friend and foe.

In this type of thinking, then, Romanía was a collection of chôrai and chôria. This suggests that the Byzantine polity and those imbued with authority at the local level, including commanders, viewed territory as a patchwork of privately held blocks of farmland (chôrai) and villages (chôria). While Byzantine law accounted for the fact that the countryside was a complex location of economic interactions, consisting of free peasants as well as landlords and their tenants, the military manuals depict them not so much imbedded in a functioning rural society as a simplified realm of villages and villagers dependent on Byzantine commanders. ${ }^{20}$ Defining territory in these ways and assigning its defence to commanders with a set of qualities that emphasized above all 'experience' relegated the landscape and its inhabitants into the strategic category of 'security' (asphaleia). Villages, villagers, and farmland were material and human resources. As security matters, they were thus analogous to other matters of concern that attracted the same vocabulary of care (asphaleia) in the military manuals: the baggage train, the children of soldiers, the army, enemy deserters, the army camp, critical resources like water while the army is under siege. ${ }^{21}$ In contrast, we are told that only inexperienced commanders and undisciplined blonde-haired barbarians like the Franks and Lombards neglected this regime of security (asphaleia). ${ }^{22}$

\section{The Village War}

Maintaining the security of villages and devastating those of the enemy meant that the village was the heart of the on-going conflicts between Byzantium and its neighbours. Targeting civilians in this way was not collateral damage, an unintended consequence of war; instead, we will see that the strategic centrality of villages in the prosecution of warfare constituted what I will call throughout this essay the 'village war.' This term, the 'village war,' emerged in scholarship on the American War in Vietnam, initially to describe the infiltration of villages by nationalist revolutionary insurgents fighting against the government of South Vietnam in the opening years of the 1960s. Just as the village constituted the source of support and ideological justification for the insurgency, U.S. advisors and military personnel likewise saw the village as the focus of counter-insurgency tactics. For all sides in this conflict, dreaming of victory necessitated protecting villages, relocating villages into defensible zones, or utterly destroying villages. ${ }^{23}$ It doesn't take much effort to find analogous examples from other conflicts. For imperialists, securing the state and its colonies has often involved gazing into the countryside to see where dangers would emerge. When empires sense that they are crumbling in their borderlands, however borderlands are defined, peasants usually pay the

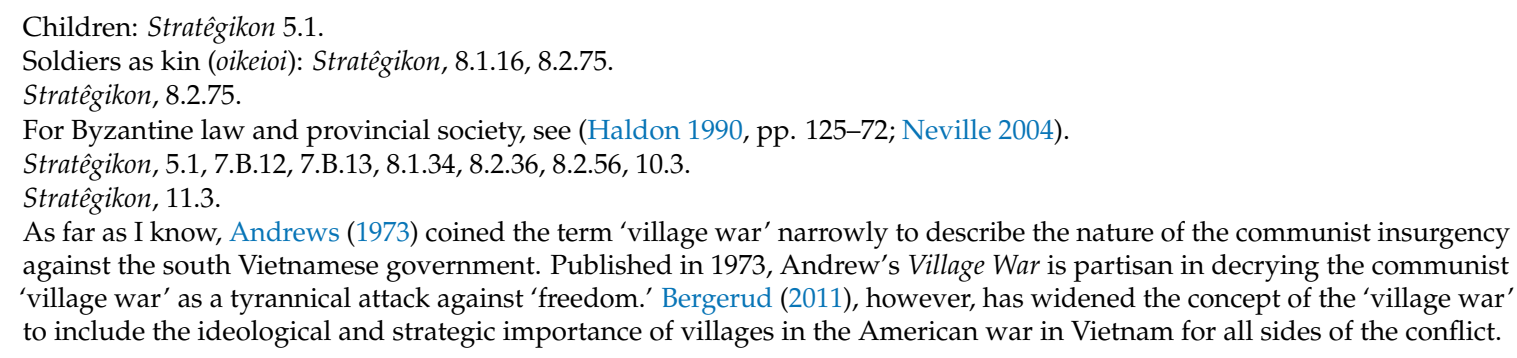


bitterest price with their lives, livestock, and futures. ${ }^{24}$ We will see that for Byzantine imperialists, like the authors of the military manuals, villages were the location of military essentials, such as grain, livestock, and horses; they supplied manpower for ad hoc militias and the setting for ingenious traps; they were the source of intelligence on the movements of the enemy; and their endangerment and security exemplified Byzantium's message of imperialist benevolence. To be sure, Byzantine military commanders did not attempt to fundamentally alter peasant society by infiltrating villages, eliminating their leadership and replacing it with nationalist ideologues. However, Byzantine frontier strategy assumed a symbiosis between the military and the peasantry: the village supplied resources and subjected itself to the directives of the emperor and his representatives in exchange for security from predatory extra-territorial enemies. As we will see, security is in the eye of the beholder.

Let us first turn to the ways in which the Byzantine polity attempted to protect villages from its own military forces. The mobile household of the commander and his army demonstrated its care for the 'people of the villages,' their flocks, and property in a variety of ways. The manuals insist on the legal duty and strategic importance of protecting local populations against unintentional harm. The anonymous sixth-century treatise, Peri Stratêgias, states with utter confidence: 'The person who wants to wage war against an enemy must first make sure that his own lands [ta oikeia] are secure [en asphaleia]. By secure [asphaleian] I mean not only the security of the army but of the cities [poleis] and the entire country [chôras], so that the people who live there [oiketoras] may suffer no harm at all from the enemy. ${ }^{\prime 25}$ The enemy was not the only concern. A major source of danger came from the army itself. The Stratêgikon mandates that soldiers who cause injury to the taxpayer (syntelestês) should be forced to pay fair compensation. In contrast to those legally tied to the land (coloni), these taxpayers were free property owners and enjoyed elevated status in their local communities. ${ }^{26}$ These damages involved the illegal rustling of livestock or the unnecessary destruction of fields. Particular care should be taken, the Stratêgikon continues, for 'cultivated fields' (geôrgêthentôn topôn) of the 'taxpayers' (hypoteleis). Thus the commander should see to it that each of his divisions marched through the fields one by one. In this way, the 'security of the farmer' (tou geôrgiou to asphales) would be ensured. ${ }^{27}$

So much for unintentional harm to the rural population at the hands of Byzantine soldiers. The strategic importance of security, as defined in official discourse, also meant that Byzantine commanders intentionally caused harm or allowed villages and their inhabitants to be harmed. The military manuals abound in such situations. They reveal that the world of the 'people of the villages' was characterized by loss of property, death, and forced mobility, and not just because of the risks that regularly characterize peasant life, such as pests, drought, and food crisis. ${ }^{28}$ Villages were prime targets in times of war, especially during the harvest season in late summer. ${ }^{29}$ Securing villages and the ripening crops around them raised the possibility of displacing villagers. In some situations, villages (chôria) were notified in advance of an enemy assault. The tenth-century Peri Paradromês calls those tasked with organizing these emergency measures ekspêlatores (Latin: expilatores). They were to direct the evacuees to take themselves and their animals to seek refuge in mountain fortresses or fortified cities. ${ }^{30}$ But these evacuees could be turned away from the fortresses and fortified cities that were at least nominally there to protect them and their property. Those deemed 'useless' (achrêston) to the military campaign would be forced to continue their miserable journey and seek refuge elsewhere, depending on the amount of supplies on hand to support the soldiers. The 'useless' included the

24 Illuminating is Drohan (2017, pp. 81-113) on British brutality in the quelling of the Nasserite Radfan revolt in the colony of Aden in the early 1960s. Drohan dubs this the 'hunger war.' We will see that there are conceptual affinities between a 'village war' and a 'hunger war.'

25 Peri Stratêgias 5.

26 Laniado (1996, pp. 30-32).

Stratêgikon, 1.9.

Garnsey (1988, pp. 8-39).

Peri Paradromês 7. See (Dennis 1985, p. 165, n. 1).

Peri Paradromês 2, 8, 12, 20, 22. 
most vulnerable: women, the elderly, and children. ${ }^{31}$ In other cases, there was no time to organize an evacuation. Commanders were therefore advised to shadow the hostile army, harassing it with feinted engagements, especially at night: 'In this way the enemy will be very much aware that the general is following them, and they will hold back and will not dare ride out at all and attack the villages [chôriôn]. By such procedures he will save the villagers from impending assault and from captivity, and they shall keep their freedom. ${ }^{32}$ This was the best possible scenario: no displacement, no death, no damage to property. Those who did lose their freedom were dragged back toward the frontier to be exploited for labour, ransom, and information. ${ }^{33}$ When possible, these captives and their possessions were rescued as the Byzantine army pursued and ambushed the homeward-bound enemy. ${ }^{34}$ At the same time, the care for locals was met with a degree of callousness. Locals would know if the Byzantine army was in the area. If some were captured by the enemy, that would be acceptable, for the enemy would come to know from these captive peasants what he was up against. The enemy might then become fearful and reconsider his assault. ${ }^{35}$

For Byzantine commanders and their enemies, villages could be the location of danger. Even a friendly village could harbour enemy spies (kataskopoi). ${ }^{36}$ They could also be the location where commanders could demonstrate their skill. Although, as we saw above, the 'security of the farmer' was a strategic concern, their evacuated villages were another matter. They presented commanders with multiple opportunities for ambuscade, and thus the village became the proxy battleground for competing armies. This is most vividly described in the tenth-century Peri Paradromês, where the predominant concern of the treatise is small-scale, rapidly executed engagements with Muslim armies of the Hamdanid emirate of Aleppo. ${ }^{37}$ Detachments of mounted soldiers-up to one hundred or so are recommended-were to hide in strategic locations outside the village. High places like hills and mountains were best, and patience was essential. From there, they could observe the enemy riding into a village. When the enemy had dismounted and began plundering the houses in search of food, coins, and other supplies, the Byzantine horsemen were to charge into the village and kill and take captive as many of the raiding party as possible. Furthermore, as the enemy took flight toward the emir's main encampment, they would encounter more Byzantine soldiers lying in wait, and more death would follow. ${ }^{38}$ The same treatise assures the reader that this advice was born of 'experience' (peira), but adds the reminder that the commander's success was dependent ultimately on the favour of god. ${ }^{39}$

This use of villages as the site for predation, abduction, and ambuscade was routine for both the Byzantine army and its enemies. As the commanders moved through the Byzantine borderlands, exercising their 'experience and courage,' these dangers and displacements constituted the normal course of life for settled populations for whom these laudable qualities of leadership did not compensate for the loss of home, property, and life. In addition to being a source of booty, evacuated villages were used as ersatz camps for Byzantine troops, and their houses could be mined for essential resources. Thus the Peri Paradromês advises commanders to torch friendly villages, especially in areas where trees were scarce, to prevent their wooden roofs from being dismantled and used by the enemy. ${ }^{40}$ Perhaps the most familiar form that the strategic destruction of village life took was the practice of intentionally ruining crops. ${ }^{41}$ Building a fortress could have devastating local consequences. According to the Stratêgikon, 'If it is summer the crops in the vicinity should be burned, but if this is

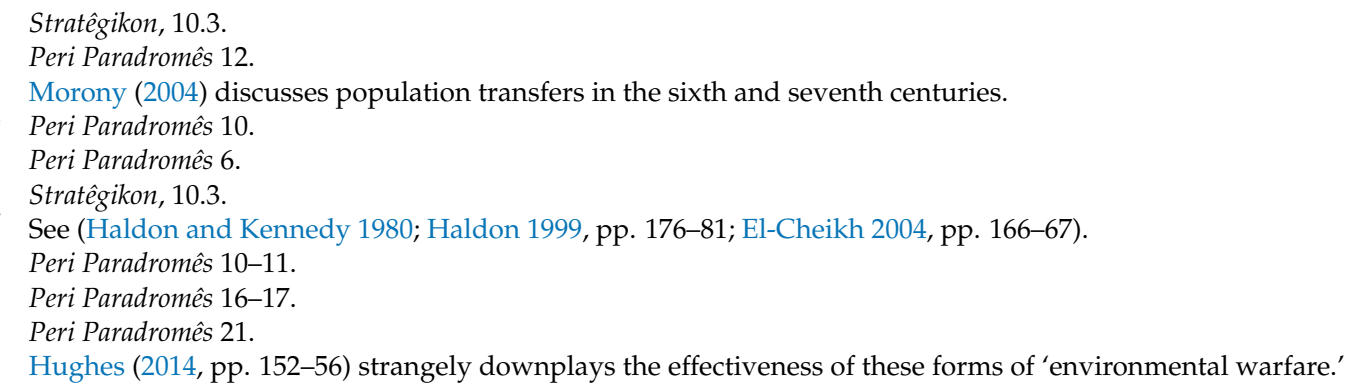


difficult to do, destroy them some other way. ${ }^{42}$ In areas surrounding fortresses, the aim was to draw as many resources as possible into the fortresses, thus turning a fertile landscape into a wasteland. Livestock was rounded up and Byzantine soldiers destroyed whatever remaining provisions were in the area, so that there was nothing left for the enemy to use. ${ }^{43}$ Moreover, this view of the landscape as potentially treasonous was paradigmatic. The Peri Stratêgias points to Justinian's famous commander, Belisarios: 'When the enemy was so large that he was unable to face up to it, he would destroy the provisions in the area before they appeared. ${ }^{44}$

Treating one's own landscape as potentially treasonous or the enemy's as potentially malevolent meant creating certain illusions. Whereas burned villages and fields were an obvious sign to the enemy that the landscape would be unyielding and the going difficult, there were less obvious ways of turning the landscape itself against the enemy-and of further endangering rural populations in the name of security. States and paramilitary forces have routinely employed officially sanctioned, if sometimes covert, forms of terrorism such as poisoning sources of water and crops. Today, this is denounced by the international community as chemical warfare, even as it continues into the present. But in the military manuals, the practice is chillingly both recommended and unremarkable. The Stratêgikon mentions this form of 'chemical warfare' twice. In the first instance, the treatise recommends employing the tactic while campaigning in enemy territory: 'The general must make plans to defeat the enemy not only by arms but also through their grain and drink [dia sitiôn kai hydatos], making the water unfit to drink and poisoning the grain. He must also know how we can protect ourselves against such measures and how we can avoid falling victim to them. ${ }^{\prime 4}$ While the treatise doesn't elaborate on how precisely to poison these resources, it does suggest how to determine if looted foodstuffs had been contaminated: 'Any wine or bread [arton] found locally should not be drunk or eaten before it has been tested by giving it to prisoners [aichmalotôn] ... Water from wells,' the author continues, 'should not be drunk for it will often have been poisoned [pharmakois]. ${ }^{\prime 46}$

This potentially lethal use of local captives in this way is mirrored in other forms of subterfuge involving the rural population. The Peri Paradromês describes an elaborate ruse led by a 'brave and very experienced man' (andreion kai empeirotaton) to draw the enemy into an ambush. He would assemble a team of up to twenty men. Some would be soldiers, some would be true farmers and shepherds, but all of them would be dressed as farmers, in particular as peasant watchmen (oikophylakes). This peasant masquerade required attention to detail. Their heads were to be uncovered, they would carry short staffs, and a few of them should be barefoot. The plan was for them to pretend to be non-combatants riding on horseback from village to village to round up cattle, horses, and mules and bring them to a fortified location. This stream of refugees (though some of the locals would have been refugees in actuality), and their precious livestock would draw the attention of the enemy. With the enemy taking the bait and charging in the direction of the ambush, the unarmed men dressed as farmers and peasant watchmen would lead the enemy right into the trap. ${ }^{47}$ It is unclear from this example if such operations were common and what effect they had on the image of the farmer for Byzantine soldiers and their enemies. At least one of the other treatises recommends another similar masquerade, this one

\footnotetext{
Stratêgikon, 10.4 .

Stratêgikon, 10.2.

Peri Stratêgias [33].

Stratêgikon, 8.2.99 (trans. adapted).

46 Stratêgikon, 9.3 (trans. adapted). 'Captive' is also an acceptable translation for aichmalôtos, suggesting that these prisoners could well have been local non-combatants in enemy territory and not necessarily enemy soldiers. Here, the Stratêgikon also gives a historical example of when a Byzantine army was successfully duped into feeding barley, poisoned by Sasanian forces, to their horses with disastrous consequences. The Chronicle of John of Nikiu, chapter 96, elaborates on this episode.

47 Peri Paradromês 21. It is unclear what is meant by oikophylax in this passage. Dennis translates the term as 'steward' and 'peasant steward.' Its usage here suggests not a village official or a free peasant household head, but rather a servant in charge of managing the day-to-day duties of an individual farm. For the oikophylax as a city official equivalent to an oikonomos in the epigraphy of Asia Minor, see Kern (1915). For the application of this title to a 'slave steward,' see Robert (1984, p. 484, n. 79).
} 
involving dressing soldiers as 'servants' (hypourgoi) and mixing themselves among actual servants. ${ }^{48}$ Byzantine commanders did, however, endeavour to sow conflict within rural communities in enemy territory by turning peasants against local elites. According to the Stratêgikon, 'A way of arousing discord and suspicion among the enemy is to refrain from burning and plundering the estates [chôria] of certain prominent men [episêmôn] on their side and of them alone. ${ }^{49}$

\section{4. 'The State of Affairs Was No Less Grievous Than Captivity'}

The military manuals discussed here only provide the view that military officials had of the landscapes of war and the rural population. For these men, 'security' necessitated a predatory relationship with respect to the rural populations on either side of the frontier. What we lack is the peasant point of view. We find hints in other forms of writing that confirms the obvious: rural populations have always been wary of state institutions, policies, and actions, especially when policies directly intrude in village life in the ways described above.

While there is limited evidence that shows peasants could be enrolled and fight in local militias, ${ }^{50}$ we are more often met with anecdotes and editorializing commentary that illustrate the point that those living in Byzantine territory sometimes experienced the presence of the Byzantine army as a hostile occupation, and that the knock-on effects of war in one region dramatically affected the lives of those living elsewhere. In the early ninth century, the Byzantine borderlands to the north were extremely troublesome. By 812/13, the Bulgar Krum (Greek: Kroummos) had succeeded in making deep raids into Byzantine Thrace. The recently inaugurated emperor Michaêl I (811-813) amassed thousands of troops along the Thracian border from the whole empire. This sparked discontent, according to the chronicle of Theophanes the Confessor, especially among those from the provinces (themata) of Kappadokia and Armenia. These discontented and displaced soldiers soon caused devastation to the settled population. Rather than attacking Krum's forces across the frontier, the emperor and his troops rambled through Byzantine Thrace, requisitioning supplies as they went. In the words of Theophanes, 'The presence of such a throng of our fellow-countrymen (homophulôn) who lacked supplies and ruined the local inhabitants (egchôrous) by rapine and invasion was more grievous than a barbarian attack. ${ }^{51}$ A few years earlier, even worse befell the locals throughout the empire. Theophanes reports that in 809/10 the emperor Nikephoros I (802-811) ordered a mass migration of people from Asia Minor to resettle in Macedonia and Greece in lands until then populated by Slavs. They were forced to sell their lands and property, resulting in misery. According to Theophanes, and allowing for embellishment, the effect for these officially sanctioned refugees was, again, worse than if they had been captured by the enemy: 'This state of affairs was no less grievous than captivity: many in their folly uttered blasphemies and prayed to be invaded by the enemy, others wept by their ancestral tombs and extolled the happiness of the dead; some even hanged themselves to be delivered from such a sorry pass. ${ }^{.52}$

The dislocations of war can be not only physical, psychological, and material, but they can also present themselves along a spectrum of difference. As hinted at above, Byzantine soldiers routinely campaigned alongside those from different regions of the empire. They also dealt with local populations whose religions and languages were distinct from their own. This was not always a welcome encounter. Though preceding the world evoked by the Byzantine military manuals and focusing on the occupation of a city and its hinterland, the Syriac chronicle of Pseudo-Joshua the Stylite illuminates the pitfalls of hosting foreign troops in the name of security. The chronicle narrates

\footnotetext{
[Anônymou Biblion taktikon] [23].

Stratêgikon, 8.1.20.

50 Theophanes, Chronographia AM 6201 (De Boor 1883-1885; Mango and Scott 1997). In this case, the peasant milita (referred to as meta ... geôrgikou laou chôrikoboêtheias) failed miserably, resulting in the Arab capture of the city of Tyana and the enslavement of some of its inhabitants. Discussed in Eger (2015, p. 251).

51 Theophanes, Chronographia AM 6305.

52 Theophanes, Chronographia AM 6302.
} 
the Byzantine occupation of his hometown Edessa in upper Mesopotamia (modern Şanlıurfa in southeastern Turkey) in 506. The emperor Anastasios amassed troops in this region to halt the advance of the Sasanian Persian army into the eastern frontier. For Joshua and the Syriac-speakers of Edessa, the Byzantine soldiers were foreigners: they were 'Romans' (Rhomâyê) and 'Goths' (Gôtâyê). The 'Roman' soldiers forced locals to draw water for them; the 'Romans' forced bakers to bake hardtack and bread at their own cost; the 'Romans' had more food, drink, and clothing than the locals. Even worse was the unrestrained behaviour of the 'Goths.' The 'Goths' seized beds and stripped off clothing from people, rounded up cattle, and plundered stores of provisions, including olive oil, wood, salt, and vegetables. They raped local women, administered unjustified beatings, and even committed murder with impunity. These foreign soldiers occupied not just the city of Edessa, but also the surrounding territory where they were billeted in villages and monasteries. Here, they rounded up cattle and abused farmers who dared to harvest their crops. All of this contributed to Joshua's condemnation of his age as 'evil times. ${ }^{53}$

These humiliations at the hands of Byzantine troops and their Gothic mercenaries were part of the storehouse of local memory. For Edessan Christians, this was just the latest example of foreign military saviours who brought destruction in the name of security. ${ }^{54}$ Just as Theophanes characterized the presence of the Byzantine army as a barbarian captivity, Joshua tells the addressee of his chronicle: 'you must be aware that when those who came to our assistance ostensibly as saviours ..., they looted us in a manner little short of enemies. ${ }^{55}$ The repetition of this sentiment in Greek and Syriac sources was perhaps drawn from a well of popular discontent that called into question the paternalism that pervades the Byzantine military manuals. While we have to rely on local elites like Joshua and monastic elites like Theophanes for reports on peasant reactions to Byzantine military operations, it is easy to find similar reactions among those who currently live in the shadow of foreign military bases and occupying forces. The recent opening of the massive US Army Garrison Humphreys just south of Seoul, South Korea has reignited decades-long protests against the U.S. military presence on the Korean peninsula. These protests have repeatedly been focused on the local cost of hosting an allied power in the name of security. As a Korean academic recently put it, 'Even if, at the end of the day, you think bases are there to provide stability and security-we think about national security, but what about human security or, at the very local level, what cost was it to have this large infrastructure in place? It's all part of the question of who defines peace and security. ${ }^{56}$ Taken together, these voices, though separated by circumstance and a vast chronological chasm, invite us to look for and imagine the ways in which peasants themselves thought of the landscapes of war differently than their masters and saviours.

\section{The Beekeeper of Dohuk}

One could conclude that some of what has been detailed above, especially the targeting of civilian populations in the name of imperial security, has to do with the type of extreme situations that the Geneva Conventions condemn. The Geneva Conventions were written with the assumption that war often results in the death and dislocation of civilians. These strictures, however, are only effective in highlighting (in a highly selective manner) the persistence of civilians being targeted by state and paramilitary armies. They rarely mitigate the ingrained habits of war that so often demand senseless violence against those ill equipped to resist soldiers with modern weaponry. Modern warfare, with its

53 Pseudo-Joshua the Stylite, Chronicle 39, 52, 54, 70, 77, 86, 93, 96, 101 (Wright 1882; Trombley and Watt 2000); Jones (1986, 1:629 n. 45) comments on Pseudo-Joshua's account of forced bread baking. Analogous is the report found in the Syriac Chronicle of Zuqnîn on the rapacious and destabilizing treatment by Muslim administrators of Syrian Christian villages in the last half of the eighth century (Harrack 1999, pp. 289-303).

54 By the fifth century, Edessan Christians celebrated the legend of a local woman's ill-fated marriage to a Gothic soldier at the end of the fourth century. See Euphemia and the Goth (Burkitt 1913).

55 Pseudo-Joshua the Stylite, Chronicle 86.

56 Letman (2017). 
drones and precision bombs, has not spared villages and villagers. Indeed, even as I write these words, the village war continues without end. In the not so distant past in Algeria, Vietnam, and Bosnia; more recently in occupied Palestine, in the Kurdish regions of northern Syria and Iraq, in the Saudi-US war against the Shia rebels of Yemen, in the Rakhine state of Myanmar, in Niger and Somalia, and in many other parts of the world. For those caught up in the violence, the response is to join others seeking refuge and flee the conflict zone.

In the historical period discussed here, the fragility and precarity of rural life was met with a sense of fatalism, but not with passive acceptance. ${ }^{57}$ Pseudo-Joshua's chronicle is an extended lamentation: the sins of the people had brought down the heavy hand of divine wrath in the form of plagues, invasions, and humiliations at the hands of would-be Roman saviours. ${ }^{58}$ Yet the chronicle also reports individual acts of resistance, such as a family protecting a Roman military official from a murderous band of Goths. ${ }^{59}$ There were also other strategies of coping with inter- and intra-communal conflict. Peter Brown has drawn attention to the functioning of Christian holy men and women as arbiters of disputes in the relatively prosperous late Roman villages of the limestone massif in northern Syria, and to sorcerers and accusations of sorcery in the same context. ${ }^{60}$ Along the Byzantine frontier, we also find in Sasanian Mesopotamia (what is now northern Iraq) that magicians began inscribing incantations on clay bowls for their clients in the sixth century and continued to do so into the seventh century when the practice fizzled out. The incantations were written in Aramaic, Syriac, Mandaic, Arabic, and Middle Persian, and they were used by Christians, Jews, Manichaeans, Mandaeans, and Zoroastrians. ${ }^{61}$ One feature of the incantations is the inclusion of a story (historiola). These stories name demons as the source of troubles, and deal with the sudden loss of family members by appealing to angels. The imagery is saturated with the language of war: '[T]he phalanx of demons and the band of no-good-ones were in commotion, the troop of the dêvs and the band of the liliths were in commotion. The drum of rebellion groaned, the horn of destruction cried out. The cauldrons boiled over with rage, the great cauldrons of destruction boiled.' ${ }^{62}$ The spells also issue threats in the language of war. In one, the evil spirit is told that its fate will be like that of someone displaced by conflict 'you evil spirit, they will ban you and break you and excommunicate you just as mighty fortified cities were broken.' And a few lines later, the evil spirit is ordered to 'be removed and be displaced and go away and depart and be abolished' from its victim. ${ }^{63}$

The incantation bowls and the presence in rural society of men and women charged with holiness as well as these more recent village wars teach us that we need to attune ourselves to how informal, non-state actors are often left with the responsibility of rectifying loss and resolving intra-communal conflict. To do so we need to return to the Yazidis of Mount Sinjar. When the Yazidis, who had managed to escape, began returning to their villages in Kurdish regions of northern Iraq in the winter of 2015, they found pits full of the remains of their families and friends hastily covered with dirt. IS had killed everyone they could, taking only women and children with them as they moved from village to village, eventually taking their victims into Syria. ${ }^{64}$ More than six thousand women and children disappeared. With scant help from state actors or supranational and international bodies, the Yazidi survivors have organized their own efforts to locate and liberate the captives. They formed secret networks of spies, operations that have involved posing as door-to-door chocolate sellers and

57 For peasant strategies of resistance in the late empire, from indifference to invasion to revolt, see De Ste. Croix (1981, pp. 474-88); more generally, MacMullen (1974, pp. 1-27); Garnsey (1988, pp. 43-68) discusses peasant survival strategies; Neville (2004, pp. 119-64) the informal ways in which provincial society in the Middle Byzantine period regulated itself.

58 Pseudo-Joshua the Stylite, Chronicle 33, 36, 38, 85-86. See Mazzarino (1966, pp. 58-76) on the 'judgments of God as an historical category.'

59 Pseudo-Joshua the Stylite, Chronicle 94.

60 (Brown 1970, 1971).

61 Morony (2003).

62 Shaked et al. (Shaked et al. 2013, p. 15: MS 2053/159).

63 Shaked et al. (2013, p. 80: JBA 9, 11. 11, 15).

64 Shapiro (2015). 
deliverymen for bakeries. In this setting, a beekeeper from the Yazidi village of Dohuk, Abdullah Shrim, found a new calling. His story shows the devastating consequences of village wars. Fifty-six of his relatives were captured by IS. Since then, he has organized the release of more than three hundred of his fellow Yazidis, each of them requiring the payment of thousands of dollars in ransom. ${ }^{65}$

We will not be able to tell in detail the stories of the Byzantine beekeepers of borderlands that were shared, and contested by, Byzantium and Sasanian Iran or the Islamic polities of the early Middle Ages. But we have to assume nonetheless that peasants picked up the pieces of lives shattered by these regimes and their representatives. For the Byzantine polity, the necessity of maintaining 'security' required conceptualizing the landscape as a zone of possibility consisting of villages. For Byzantine commanders, the quality of 'experience' meant knowing how best to exploit this zone of possibility to forestall large- and small-scale defeats and to secure victory with the least amount of casualties. They did so in part by destroying villages, using them and their inhabitants in ambushes, poisoning and seizing their crops, evacuating them, and using them for the billeting of soldiers. Villages were thus central to a Byzantine military strategy that I have glossed as the 'village war.' Throughout this essay, I have juxtaposed premodern and modern modalities of war as a pointed reminder that the village war is in the water, so to say, of imperialist and nationalist thinking. Ignoring the village war in the past and the present, or attributing its prosecution to a barbarian Other, is to turn a blind eye to those displaced by war, to validate the justification of suffering in the name of security, and to participate in various forms of imperial and colonial nostalgia. To borrow an observation from the historian Santo Mazzarino, empires can be the 'object of infinite love as well as infinite hatred. ${ }^{66}$ This essay has asked us to imagine that the same was as true for those living in the borderlands of the Byzantine empire as it has been for those living in the shadow of empires of the more recent past.

Funding: This research received no external funding.

Acknowledgments: The author wishes to thank Elena Isayev, Evan Jewell, and Malcolm Sen for their many incisive suggestions.

Conflicts of Interest: The author declares no conflict of interest.

\section{References}

Andrews, William R. 1973. The Village War: Vietnamese Communist Revolutionary Activities in Dinh Tuong Province, 1960-1964. Columbia: University of Missouri Press.

Andrews, Kehinde. 2016. Colonial nostalgia is back in fashion, blinding us to the horrors of empire. The Guardian, August 24. Available online: https://www.theguardian.com/commentisfree/2016/aug/24/colonialnostalgia-horrors-of-empire-britain-olympic (accessed on 22 August 2018).

Arraf, Jane. 2018. This Man has Freed Hundreds of Yazidis Captured by ISIS. Thousands Remain Missing. National Public Radio, January 18. Available online: https: / www.npr.org/sections/parallels/2018/01/18/578313469/ (accessed on 22 August 2018).

Bergerud, Eric. 2011. The Village War in Vietnam, 1965-1973. In The Columbia History of the Vietnam War. Edited by David L. Anderson. New York: Columbia University Press, pp. 262-96.

Brown, Peter. 1970. Sorcery, Demons, and the Rise of Christianity from Late Antiquity into the Middle Ages. In Witchcraft: Confessions and Accusations. Edited by Mary Douglas. London: Tavistock, pp. 17-45.

Brown, Peter. 1971. The Rise and Function of the Holy Man in Late Antiquity. JRS 61: 80-101. [CrossRef]

Burkitt, Francis Crawford, ed. 1913. Euphemia and the Goth, with the Acts of Martyrdom of the Confessors of Edessa. London and Oxford: Williams and Norgate.

Dain, Alphonse. 1967. Les stratégistes byzantins. TM 2: 317-92.

65 Arraf (2018).

66 Mazzarino (1966, p. 51). 
Dalal, Ayham. 2017. Uncovering Culture and Identity in Refugee Camps. In Displacement and the Humanities: Manifestos from the Ancient to the Present. Edited by Elena Isayev and Evan Jewell. Special issue, Humanities 6: 54 .

De Boor, Carolus, ed. 1883-1885. Theophanis Chronographia. Leipzig: Teubner.

De Ste. Croix, G. E. M. 1981. The Class Struggle in the Ancient Greek World: From the Archaic Age to the Arab Conquests. London: Duckworth.

Dennis, George T., ed. 1981. Das Strategikon des Maurikios. Translated by Ernst Gamillscheg. Corpus Fontium Historiae Byzantinae 17. Vienna: Verlag der Österreichischen Akademie der Wissenschaften.

Dennis, George T. 1984. Maurice's Strategikon: Handbook of Byzantine Military Strategy. Philadelphia: University of Pennsylvania Press.

Dennis, George T., ed. 1985. Three Byzantine Military Treatises: Text, Translation, and Notes. Corpus Fontium Historiae Byzantinae 25. Washington, DC: Dumbarton Oaks Research Library and Collection.

Dennis, George T. 2001. Defenders of the Christian People: Holy War in Byzantium. In The Crusades from the Perspective of Byzantium and the Muslim World. Edited by Angeliki E. Laiou and Roy Parviz Mottahedeh. Washington, DC: Dumbarton Oaks Research Library and Collection, pp. 31-39.

Drohan, Brian. 2017. Brutality in an Age of Human Rights: Activism and Counterinsurgency at the End of the British Empire. Ithaca: Cornell University Press.

Eger, A. Asa. 2015. The Islamic-Byzantine Frontier: Interaction and Exchange among Muslim and Christian Communities. London and New York: I.B. Tauris.

El-Cheikh, Nadia Maria. 2004. Byzantium Viewed by the Arabs. Cambridge: Harvard University Press.

Garnsey, Peter. 1988. Famine and Food Supply in the Graeco-Roman World: Responses to Risk and Crisis. Cambridge: Cambridge University Press.

Grosse, Robert. 1975. Römische Militärgeschichte von Gallienus bis zum Beginn der byzantinischen Themenverfassung. New York: Arno Press. First Published 1920.

Haldon, John F. 1990. Byzantium in the Seventh Century: The Transformation of a Culture. Cambridge: Cambridge University Press.

Haldon, John F. 1995a. The Army and the Economy: The Allocation and Redistribution of Surplus Wealth in the Byzantine State. In State, Army and Society in Byzantium: Approaches to Military, Social and Administrative History. Aldershot: Variorum Reprints.

Haldon, John F. 1995b. Military Service, Military Lands and the Status of Soldiers: Current Problems and Interpretations. In State, Army and Society in Byzantium: Approaches to Military, Social and Administrative History. Aldershot: Variorum Reprints.

Haldon, John F. 1999. Warfare, State and Society in the Byzantine World 565-1204. London: UCL Press.

Haldon, John F., and Hugh Kennedy. 1980. The Arab-Byzantine Frontier in the Eighth and Ninth Centuries: Military Organization and Society in the Borderlands. Zbornik Radova Vizantološkog Instituta 19: 79-117.

Harrack, Amir. 1999. The Chronicle of Zuqnîn, Parts III and IV, A.D. 488-775. Toronto: Pontifical Institute of Mediaeval Studies.

Hughes, J. Donald. 2014. Environmental Problems of the Greeks and Romans: Ecology in the Ancient Mediterranean, 2nd ed. Baltimore: Johns Hopkins University Press.

Jones, Arnold Hugh Martin. 1986. The Later Roman Empire 284-602: A Social, Economic, and Administrative Survey. 2 vols. Baltimore: The Johns Hopkins University Press.

Kaegi, Walter Emil. 1981. Byzantine Military Unrest, 471-843: An Interpretation. Amsterdam: Hakkert.

Kaegi, Walter Emil. 1982. Some Reconsiderations on the Themes (Seventh to Ninth Centuries). London: Variorum Reprints.

Kaldellis, Anthony. 2017. Did the Byzantine Empire Have 'Ecumenical' or 'Universal' Aspirations? In Ancient States and Infrastructural Power: Europe, Asia, and America. Edited by Clifford Ando and Seth Richardson. Philadelphia: University of Pennsylvania Press, pp. 272-300.

Kern, Otto. 1915. OІКОФY $\Lambda$ AKE $\Sigma$. Hermes 50: 154-58.

Krsmanović, Bojana. 2008. The Byzantine Province in Change (On the Threshold Between the 10th and 11th Century). Belgrade: Serbian Academy of Sciences and Arts, Institute for Byzantine Studies. 
Landler, Mark, Alissa J. Rubin, Mark Mazzetti, and Helene Cooper. 2014. Fear of 'Another Benghazi' Drove White House to Airstrikes in Iraq. New York Times. August 8. Available online: https:/ / www.nytimes.com/2014/ 08/09/world/middleeast/fear-of-another-benghazi-drove-white-house-to-airstrikes-in-iraq.html (accessed on 22 August 2018).

Laniado, Avshalom. 1996. $\Sigma v \vee \tau \varepsilon \lambda \varepsilon \sigma \tau \eta ́$ s: Notes sur un terme fiscal surinterprété. Journal of Juristic Papyrology 26: 23-51.

Letman, Jon. 2017. USAG Humphreys: The Story behind America's Biggest Overseas Base. The Diplomat. Available online: https:/ / thediplomat.com/2017/11/camp-humphreys-the-story-behind-americas-biggestoverseas-base/ (accessed on 22 August 2018).

MacMullen, Ramsay. 1974. Roman Social Relations 50 B.C. to A.D. 284. New Haven: Yale University Press.

Mango, Cyril, and Roger Scott. 1997. The Chronicle of Theophanes Confessor: Byzantine and Near Eastern History AD 284-813. Oxford: Clarendon Press.

Maqusi, Samar. 2017. 'Space of Refuge': Negotiating Space with Refugees inside the Palestinian Camp. Humanities 6: 54. [CrossRef]

Mazzarino, Santo. 1966. The End of the Ancient World. Translated by George Holmes. New York: Alfred A. Knopf. McGeer, Eric. 1991. Tradition and Reality in the Taktika Nikephoros Ouranos. DOP 45: 129-40. [CrossRef]

McGeer, Eric. 1995. Sowing the Dragon's Teeth: Byzantine Warfare in the Tenth Century. Washington, DC: Dumbarton Oaks Research Library and Collection.

Missing Migrants Project. 2013-2018. Spotlight on the Mediterranean. International Organization for Migration (IOM). Available online: https:/ /missingmigrants.iom.int/region/mediterranean (accessed on 15 August 2018).

Morony, Michael G. 2003. Magic and Society in late Sasanian Iraq. In Prayer, Magic, and the Stars in the Ancient and Late Antique World. Edited by Scott Noegel, Joel Walker and Brannon Wheeler. University Park: Pennsylavian State University Press, pp. 83-107.

Morony, Michael G. 2004. Population Transfers between Sasanian Iran and the Byzantine Empire. In Persia e Bisanzio: Convegno Internazionale: Roma, 14-18 Ottobre 2002. Rome: Accademia Nazionale dei Lincei, pp. 161-79.

Neville, Leonora. 2004. Authority in Byzantine Provincial Society, 950-1100. Cambridge: Cambridge University Press.

Petti, Alessandro. 2017. Refugee Heritage. Part III Justification for Inscription. Humanities 6: 54. [CrossRef]

Prashad, Vijay. 2017a. Third World Quarterly row: Why some western intellectuals are trying to debrutalise colonialism. Scroll.in. September 21. Available online: https://scroll.in/article/851305/thirdworld-quarterly-row-why-some-western-intellectuals-are-trying-to-debrutalise-colonialism (accessed on 22 August 2018).

Prashad, Vijay. 2017b. For Children All over the World, 2017 was Defined by War: Generations Cannot Imagine Life without Violence. Alternet. December 27. Available online: https://www.alternet.org/world/childrenall-over-world-2017-was-defined-war (accessed on 22 August 2018).

Robert, Louis. 1984. Documents d'Asie Mineure. BCH 108: 457-532. [CrossRef]

Rubin, Alissa J. 2014. For Refugees on Mountain, 'No Water, Nothing.'. New York Times. August 9. Available online: https:/ /www.nytimes.com/2014/08/10/world/middleeast/chased-onto-iraqi-mountain-thereis-no-water-nothing.html (accessed on 22 August 2018).

Shaked, Shaul, Siam Bhayro, and James Nathan Ford, eds. 2013. Aramaic Bowl Spells: Jerwish Babylonian Aramaic Bowls. Leiden: Brill.

Shapiro, Ari. 2015. In a Somber Homecoming, Yazidis Grieve and Watch over their Dead. National Public Radio. February 12. Available online: https:/ / www.npr.org/sections/parallels/2015/02/12/385712996/ (accessed on 22 August 2018).

Shefler, Gil. 2014. Islamic State Accused of Capturing Yazidi Women and Forcing Them to Convert, or Else. Washington Post, August 7. Available online: https://www.washingtonpost.com/national/religion/islamicstate-accused-of-capturing-yazidi-women-and-forcing-them-to-convert-or-else/2014/08/07/5e6080ba1e70-11e4-9b6c-12e30cbe86a3_story.html (accessed on 22 August 2018).

Treadgold, Warren. 1995. Byzantium and its Army, 284-1081. Stanford: Stanford University Press.

Tripathi, Salil. 2018. Empire Strikes Back: Why Former Colonies Don't Need Britain after Brexit. The Guardian, March 9. Available online: https:/ / www.theguardian.com/business/2018/mar/10/empire-strikes-backwhy-former-colonies-dont-need-britain-after-brexit (accessed on 22 August 2018). 
Trombley, Frank R., and John W. Watt. 2000. The Chronicle of Pseudo-Joshua the Stylite. Translated Texts for Historians 32. Liverpool: Liverpool University Press.

Wright, William, ed. 1882. The Chronicle of Joshua the Stylite. Cambridge: University Press.

Zerubavel, Eviatar. 2003. Time Maps: Collective Memory and the Social Shape of the Past. Chicago: University of Chicago Press. 